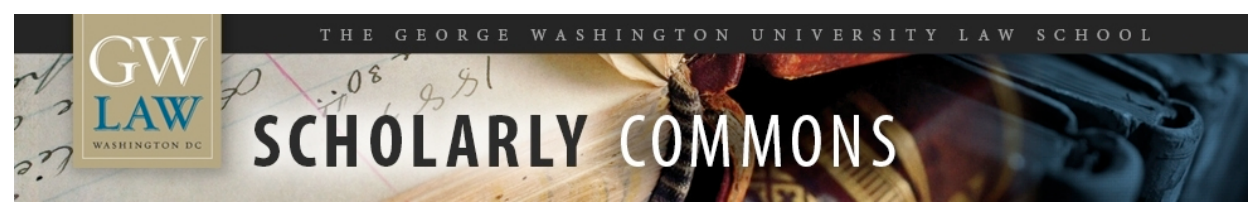

\title{
The U.S. Federal Trade Commission Workshop on Non-Compete Clauses
}

Richard J. Pierce Jr

George Washington University Law School, rpierce@law.gwu.edu

Follow this and additional works at: https://scholarship.law.gwu.edu/faculty_publications

Part of the Law Commons

\section{Recommended Citation}

Public Utilities Review, Forthcoming.

This Article is brought to you for free and open access by the Faculty Scholarship at Scholarly Commons. It has been accepted for inclusion in GW Law Faculty Publications \& Other Works by an authorized administrator of Scholarly Commons. For more information, please contact spagel@law.gwu.edu. 


\section{THE GEORGE WASHINGTON UN IVERSITY LAW SCHOOL}

GW Law School Public Law and Legal Theory Paper No. 2020-01

GW Legal Studies Research Paper No. 2020-01

\section{The U.S. Federal Trade Commission Workshop on Non- Compete Clauses}

Richard J. Pierce, Jr.

Public Utilities Review, 2020 Forthcoming.

This paper can be downloaded free of charge from the Social Science Research

Network: https://ssrn.com/abstract=3520009 


\title{
The U.S. Federal Trade Commission Workshop on Non-Compete Clauses
}

\begin{abstract}
On January 9, 2020, the FTC held a workshop on non-compete clauses. Professor Pierce wrote this article for a journal that is published in London primarily lawyers and economists in the UK and the EU. He describes the powerful evidence that supports the need for the FTC to take some action to reduce the growing trend to include non-compete clauses in many employment contracts and the difficult task the FTC faces in deciding how to address that problem.
\end{abstract}

Richard J. Pierce, Jr.

To its credit, the U.S. Federal Trade Commission (FTC) is conducting a series of workshops at which scholars discuss the most important issues that competition authorities need to address at present. This is a summary of the workshop the FTC held on January 9 on non-compete clauses in employment contracts. The workshop was organized to discuss the requests of several organizations that FTC issue a rule that prohibits all non-compete clauses. The workshop began with a summary of the law applicable to non-compete clauses. It then proceeded to a discussion of the evidence that suggests that non-compete clauses are having serious adverse effects on the performance of markets. It concluded with a discussion of the steps that the FTC should take to address the growing problems created by non-compete clauses.

\section{The Law Applicable to Non-Compete Clauses}

Common law courts have recognized that non-compete clauses in employment contracts interfere with the performance of competitive labor markets for centuries. Common law courts tolerate their anti-competitive effects only when they have a "good foundation" and are subject to reasonable limits on their scope and duration. ${ }^{1}$ States in the U.S. vary greatly with respect to their tolerance for noncompete clauses. Some states ban all non-compete clauses, while others readily accept a variety of justifications for broad non-compete clauses. ${ }^{2}$ Some states have modified the common law governing non-compete clauses by statute. Thus, for instance, California has prohibited non-compete clauses by statute for over a century. Some professional organizations also prohibit non-compete clauses. Thus, for instance, the American Bar Association reaffirmed its view that non-compete clauses are unethical in an opinion issued on December 4, 2019. ${ }^{3}$

The anti-competitive effects of non-compete clauses are obvious. They allow firms to avoid matching the salaries and working conditions offered by their competitors and allow firms to lock in employees for long periods of time. They are most frequently justified by the belief that they encourage employers to make investments in employee training and research and development. They accomplish that by protecting employers from the risk that employees will leave and provide competitors with the

\footnotetext{
${ }^{1}$ E.g., Mitchell v. Reynolds, 24 Eng. Rep. 347 (Q.B. 1711).

${ }^{2}$ Phillip Thomas, Would California Survive the Move Act?: a Pre-emption Analysis of Employee Noncompetition Law, 2017 U. Chi. Legal Forum, 823, 826-33 (2017).

${ }^{3}$ ABA Standing Committee on Ethics and Professional Responsibility, Formal Opinion 489. Obligations Related to Notice when Lawyers Change Firms (Dec. 4, 2019).
} 
fruits of the efforts of the employer to train its employees and to provide the employees access to the firm's trade secrets.

In antitrust law, non-compete clauses are vertical restraints on trade that have the potential to violate the Sherman Act. Antitrust courts have adopted an approach to non-compete clauses that is similar to the common law approach. Courts apply the rule of reason to hold that a non-compete clause is lawful if it is ancillary to, and justified by, a transaction or relationship that furthers the public interest and it is reasonable in scope and duration. ${ }^{4}$ Given the overlap between contract law and antitrust law in this context and the similarity of the tests courts use to apply both to non-compete clauses, it is not surprising that antitrust law has played only a minor role in regulating non-compete clauses.

\section{Increased Use of Non-Compete Clauses}

Non-compete clauses have long been used in contracts between employers and the high level corporate executives and other highly-educated employees who have access to a firm's trade secrets. Over the last few years, however, the use of non-compete clauses has increased dramatically. They now are included in somewhere between $20 \%$ and $50 \%$ of all employment contracts, including contracts between employers and low paid employees like workers in fast food restaurants, janitors, and delivery drivers.

In these contexts, the contracts are classic contracts of adhesion. They are not the subject of negotiation between employers and employees. In most cases, the employee is not even aware that the contract includes a non-compete clause until the employee announces an intent to quit to take a job with a competitor. At that point the employer typically brings the clause to the attention of the employee and threatens legal action if the employee follows through with the expressed intent to quit to take a job with a competitor. That threat is almost invariably effective in discouraging the employee from quitting.

The incidence of non-compete clauses does not vary between the states that enforce noncompete clauses and the states that have declared them to be illegal. States that refuse to enforce noncompete clauses have the same high proportion of employment contracts with non-compete clauses as do states that enforce non-compete clauses. The vast majority of employees do not have access to the services of a lawyer who can tell the employee that the non-compete clause in her contract is illegal and unenforceable. Thus, the existence of an illegal and unenforceable non-compete clause and the threat to take legal action against an employee who quits to take a job with a competitor is almost always effective in deterring the employee from taking that action.

\section{Non-Compete Clauses Contribute to the Growing Disparity in Income and Wealth}

For several decades, the gap between the rich and the poor in the U.S. has grown rapidly. That gap is creating serious economic and political problems. The increasing gap between rich and poor has many sources, but imperfections in labor markets in general and increasing use of non-compete clauses in particular are among the leading causes.

In theory, wages and labor productivity should correlate nearly perfectly. Until 1979, wages increased at about the same rate as increases in labor productivity. Since then, however, productivity has

\footnotetext{
${ }^{4}$ Ioana Marinescu \& Herbert Hovenkamp, Anticompetitive Mergers in Labor Markets, 94 Indiana L. J. 1031, 105457 (2019).
} 
increased much more than wages, creating a large gap between productivity and wages that can only be explained as a symptom of serious imperfections in labor markets. ${ }^{5}$

During the same period, a large and growing gap has emerged between the wages paid by the most profitable firms and the least profitable firms for the same units of labor. ${ }^{6}$ That gap is also inconsistent with a properly performing competitive labor market. Many scholars attribute the growing disparity between the profitability of dominant firms and their smaller competitors to the relaxation of the antitrust limits on vertical restraints.

This combination of symptoms of market imperfections is enabled and exacerbated by noncompete clauses in employment contracts. Dominant firms use the clauses to preclude their employees from switching to other firms, to exercise their market power to depress wages, and to avoid sharing their profits with employees to the extent that a competitive market would require.

The scholars who are writing in this area fault antitrust law for tolerating vertical restraints that firms use to obtain and maintain market power in both product markets and labor markets and for ignoring pursuit of employee welfare as a goal of antitrust law. ${ }^{7}$ They urge antitrust enforcement agencies to reconsider the legality of many of the practices and contractual relationships that are increasingly implicated in studies of the causes of undue concentration in both product markets and labor markets and to adopt employee welfare as a goal of antitrust law that should be on a par with the goal of consumer welfare.

\section{The Justifications for Non-Compete Clauses Are Weak}

Non-compete clauses have been justified by the belief that they encourage employers to invest in employee training and trade secrets by providing employers a means of protecting those investments. The theoretical case in support of non-compete clauses is seriously incomplete, however, and it has weak empirical support.

Non-compete clauses are not necessary to protect trade secrets. Employers have access to other means of protecting trade secrets. Every state allows employers to sue employees and former employees for theft of trade secrets, and many states also have statutes that make it a crime to steal a trade secret.

Non-compete clauses reduce the incentive for employees to invest in their own human capital by reducing the returns they can earn on those investments. Moreover, non-compete clauses reduce the positive spillover effects of both employee mobility and information flows among competing firms.

\footnotetext{
${ }^{5}$ See Economic Policy Institute, The Productivity-Pay Gap (2018); Thomas Pikety, Emmanuel Saez \& Gabriel Zucman, Distributional National Accounts: Methods and Estimates for the United States, 133 Q.J. econ. 2, 533-609 (2018); David Autor, et al., The Fall of the Labor Share and the Rise of Superstar Firms, Nat'l Bureau of Econ. Res. Working Paper No.23396 (2017).

${ }^{6}$ John Aboud et al., Earnings Inequality and Mobility Trends in the United States, Nat'l Bureau of Econ. Res. Working Paper No. 23224 (2017).

${ }^{7}$ E.g., Marshall Steinbaum, Antitrust, the Gig Economy and Labor Market Power, 82 L. \& Cont. Prob. 45 (2019).
} 
Recent empirical studies have found that non-compete clauses have significant adverse economic effects. ${ }^{8}$ States that prohibit non-compete clauses experience significantly greater innovation and stronger economic performance than states that enforce widespread strong non-compete clauses.

\section{Antitrust Law Should Reflect Greater Concern About the Effects of Vertical Restraints}

Between 1975 and 2020, antitrust enforcement agencies and courts changed their views about vertical restraints on competition. This change was induced by scholarly writing by economists and economically literate law professors that provided theoretical support for the belief that many of the practices and contractual relationships that had previously been held to violate antitrust law were either harmless or socially beneficial. ${ }^{9}$

There is a growing consensus among antitrust scholars that the movement toward increased tolerance of vertical restraints on competition has gone too far. There is increasing evidence that many vertical restraints have serious adverse effects in many important contexts. Recent issues of law journals are full of articles and symposiums that include studies that find that many vertical restraints harm markets and that propose changes in antitrust law that are intended to respond to the problems caused by vertical restraints. ${ }^{10}$ Steven Salop's views are representative: "Strong enforcement is particularly important in markets where economies of scale and network effects lead to barriers to entry and durable market power." 11

Non-compete clauses are a type of vertical constraint on competition. Given their adverse effects on employee mobility, competitive conditions in labor markets, wages, distribution of wealth, innovation, and economic performance, coupled with their weak justification, they provide a good place to start the process of revising the approach of antitrust enforcement agencies to vertical restraints. The author of the leading Treatise on Antitrust Law, Herb Hovenkamp, has identified antitrust law's historic failure to deal adequately with labor markets as a problem that needs to be addressed. ${ }^{12}$ He has also identified the increased use of non-compete clauses as a disturbing trend that should attract the attention of antitrust enforcement agencies.

\section{Procedures Available to FTC to Address Non-Compete Clauses}

Non-compete clauses are a good candidate for a rulemaking. Unfortunately, the statutes the FTC has the power to implement have features that make it difficult for the FTC to issue rules. The FTC has no power to issue rules to implement the two primary antitrust statutes - the Sherman Act and the Clayton Act. It can enforce those statutes only by bringing cases against firms that it believes to be in violation of the statutes.

The FTC also has responsibility to enforce section five of the Federal Trade Commission Act. That section gives the FTC power to determine that an act or practice is illegal because it is an "unfair method

\footnotetext{
8 On Amir \& Orly Lobel, Driving Performance: A Growth Theory of Noncompete Law, 16 Stan. Tech. L. Rev. 833, 844-68 (2013).

${ }^{9}$ See generally Thomas Morgan \& Richard Pierce, Cases and Materials on Modern Antitrust Law and Its Origins 453-774 (6 $6^{\text {th }}$ ed. 2018).

${ }^{10}$ See, e.g., Antitrust, Symposium on Vertical Merger Enforcement (summer 2019).

${ }^{11}$ Steven Salop, Invigorating Vertical Merger Enforcement, 127 Yale L. J. 1962 (2018).

${ }^{12}$ Herbert Hovenkamp, Whatever Did Happen to the Antitrust Movement? 94 Notre Dame L. Rev. 583, 628-36 (2018).
} 
of competition" or "an unfair or deceptive act or practice." The FTC has the power to issue rules to implement section five.

Section five is broad enough to support the issuance of a rule that prohibits or limits non-compete clauses. The breadth of the statute is a source of problems, however. Courts are reluctant to uphold attempts by the FTC to take an action that is based solely on section five because of concern that the open-ended nature of the power conferred by section five might allow the FTC to take actions beyond those that Congress contemplated when it enacted the statute in 1914. Congress was so concerned about the potential for the FTC to overreach in implementing section five that it amended the statute in 1975 by adding a long list of burdensome and time-consuming procedures to the already demanding notice and comment procedure that all agencies must use to issue rules. That statutory amendment created a situation in which the FTC has rarely attempted to issue rules to implement section five. ${ }^{13}$

During the workshop, I urged the FTC to issue a guidance document in which it announces its interpretation of the Sherman Act and section five of the FTC Act as those statutes apply to non-compete clauses and its policies with respect to enforcement of competition law in the context of non-compete clauses. The FTC is not required to use any burdensome procedures in the process of issuing a guidance document. ${ }^{14}$ The FTC has complete discretion with respect to the procedures it uses to issue a guidance document.

A guidance document cannot be the basis for any formal action. The FTC can enforce the statutory interpretations and policies announced in a guidance document only through adjudications in which the FTC must support its interpretations and policies with evidence and reasoning. Even though guidance documents have no formal legal effect, they can serve many good purposes.

Most firms act in accordance with guidance documents even though they have no formal legal effect. Guidance documents place firms on notice that some types of conduct will place them in jeopardy of being held to have violated the law. That greatly reduces the likelihood that firms will act in ways that a guidance document characterizes as unlawful and identifies as a target of agency enforcement actions. One of the effects of a guidance document is to enlist the assistance of lawyers in private practice who inform their clients of an agency's interpretations of statutes and enforcement policies that are announced in guidance documents.

State legislatures and courts are also likely to be influenced by a guidance document that announces and explains in detail why FTC has adopted the statutory interpretation and enforcement policy announced in the document. The effects of the guidance document are likely to be felt both in labor law and in state antitrust law.

The guidance document should announce that the FTC interprets the Sherman Act and section five of the FTC Act to establish a presumption that non-compete clauses are unlawful and that the FTC is making enforcement of that statutory interpretation a priority. FTC should follow-up on the issuance of the guidance document by initiating actions against firms that include broad non-compete clauses in their

\footnotetext{
${ }^{13}$ See Jeffrey Lubbers, It's Time to Remove the "Mossified" Procedures for FTC Rulemaking, 83 Geo.W.L. Rev. 1979 (2015); Richard Pierce, The Rocky Relationship Between the Federal Trade Commission and Administrative Law, 83 Geo.W.L. Rev. 2026 (2015).

${ }^{14}$ Kristin Hickman \& Richard Pierce, Administrative Law Treatise chapters 4 and 5 (6 $6^{\text {th }}$ ed. 2019).
} 
employment contracts, beginning with firms that include non-compete clauses in contracts with low paid employees. It is unimaginable that any firm can justify use of non-compete clauses in that context.

Several participants in the workshop argued that the FTC should instead issue a rule under section five of the FTC Act in which it declares that non-compete clauses are illegal in specified circumstances. Such a rule would have major advantages over a guidance document. It would have the same force and effect as a statute, so it would be easy to enforce. Moreover, the notice and comment process would permit the public and regulated firms to participate in the process of shaping the rule. The proponents of that approach believe that those advantages justify the years of effort required to issue such a rule.

\section{Conclusion}

Whether the FTC acts by issuing a guidance document coupled with enforcement actions against individual firms or by issuing a rule, the FTC' s initial action is unlikely to take the form of a determination that all non-compete clauses are unlawful. There was a broad consensus among the participants in the workshop that the studies of non-compete clauses that are available to the FTC today are inadequate to support such a complete prohibition. Thus, for instance, there are studies that find that non-compete clauses have socially-beneficial effects in the context of doctors and corporate chief executives.

There was widespread agreement that any rule or guidance document that the FTC issues on noncompete clauses will have to be limited in scope to low paid workers or workers who do not have access to trade secrets or will have to exempt some high level employees. There was also broad agreement that the FTC's excellent staff of economists should undertake additional studies of the effects of non-compete clauses to fill some of the gaps in our knowledge that exist today. 